Arch Microbiol (1988) 149:447-450

\title{
Characterization of Desulfovibrio fructosovorans sp. nov.
}

\author{
B. Ollivier ${ }^{1}$, R. Cord-Ruwisch ${ }^{2}$, E. C. Hatchikian ${ }^{3}$, and J. L. Garcia ${ }^{2}$ \\ 1 Laboratoire de Microbiologie ORSTOM, ENSUT, BP 5085, Dakar, Sénégal \\ 2 Laboratoire de Microbiologie ORSTOM, Université de Provence, 3 Place Victor Hugo, F-13331 Marseille Cédex 3, France \\ 3 Laboratoire de Chimie Bactérienne, CNRS, BP 71, F-13277 Marseille Cédex 9, France
}

\begin{abstract}
Desulfovibrio strain JJ isolated from estuarine sediment differed from all other described Desulfovibrio species by the ability to degrade fructose. The oxidation was incomplete, leading to acetate production. Fructose, malate and fumarate were fermented mainly to succinate and acetate in the absence of an external electron acceptor. The $\mathrm{pH}$ and temperature optima for growth were 7.0 and $35^{\circ} \mathrm{C}$ respectively. Strain JJ was motile by means of a single polar flagellum. The DNA base composition was $64.13 \% \mathrm{G}+\mathrm{C}$. Cytochrome $c_{3}$ and desulfoviridin were present. These characteristics established the isolate as a new species of the genus Desulfovibrio, and the name Desulfovibrio fructosovorans is proposed.
\end{abstract}

Key words: Sulfate reduction - Fermentation - Fructose - Desulfovibrio fructosovorans sp. nov.

Among the sulfate-reducing bacteria, the genus Desulfovibrio was known to have a very limited range of oxidizable substrates including hydrogen, ethanol, lactate, formate, malate, fumarate and succinate (Postgate 1979). Recently, Desulfovibrio strains were isolated that utilize amino acids (Stams et al. 1985), methanol and other alcohols (Braun and Stolp 1985; Nanninga and Gottschal 1986). The newly described Desulfovibrio sapovorans and D. baarsii differed from the formerly known "classical" Desulfovibrio species by the fact they used fatty acids (Widdel 1980; Widdel and Pfennig 1984).

There are few reports on the utilization of sugars by sulfate-reducers. Desulfotomaculum nigrificans is the only sulfate-reducing bacterium described so far that uses fructose whether sulfate is present or not (Klemps et al. 1985). In the present paper, we report on a new strain of the "classical" $\mathrm{H}_{2}$-oxidizing Desulfovibrio group.

\section{Materials and methods}

Source of organism

Desulfovibrio strain JJ was kindly provided by W. J. Jones, University of Illinois at Urbana Champaign, USA. It was isolated from estuarine sediment and was used as hydrogen oxidizing bacterium in a defined mixed bacterial culture

Offprint requests to: J. L. Garcia on sucrose (Jones et al. 1984). It was tentatively named D. vulgaris strain JJ. Further experiments showed that strain JJ metabolized fructose (Cord-Ruwisch et al. 1986). The fructose grown culture has been serially diluted and inoculated into roll tubes containing $\mathrm{H}_{2}$, fructose or lactate. Picked colonies were able to grow on fructose (CordRuwisch et al. 1986).

\section{Culture medium}

Desulfovibrio strain JJ was cultured on medium containing: $\mathrm{NH}_{4} \mathrm{Cl}, 1.0 \mathrm{~g} ; \mathrm{K}_{2} \mathrm{HPO}_{4}, 0.3 \mathrm{~g} ; \mathrm{MgCl}_{2} \cdot 6 \mathrm{H}_{2} \mathrm{O}, 0.2 \mathrm{~g}$; L-cysteine - $\mathrm{HCl} ; 0.5 \mathrm{~g} ; \mathrm{CH}_{3} \mathrm{COONa} \cdot 3 \mathrm{H}_{2} \mathrm{O}, 1.0 \mathrm{~g}$; $\mathrm{Na}_{2} \mathrm{SO}_{4}, 3.0 \mathrm{~g}$; fructose, $4.0 \mathrm{~g}$; yeast extract (Difco Laboratories, Detroit, MI, USA), $1.0 \mathrm{~g}$; resazurin, $0.001 \mathrm{~g}$; mineral solution no. 2 (Balch et al. 1979), $50 \mathrm{ml}$; trace minerals solution (Balch et al. 1979), $5 \mathrm{ml}$; destilled water, 1,000 $\mathrm{ml}$. The medium was adjusted to $\mathrm{pH} 7.0$ with $10 \mathrm{M} \mathrm{KOH}$, then boiled under a stream of $\mathrm{O}_{2}$-free $\mathrm{N}_{2}-\mathrm{CO}_{2}(80-20 \%)$ and cooled to room temperature. $5 \mathrm{ml}$ of medium were distributed into Hungate tubes using the anaerobic technique of Hungate (1969). After autoclaving $\left(120^{\circ} \mathrm{C}\right.$ for $\left.20 \mathrm{~min}\right), 0.05 \mathrm{ml}$ of $2 \% \mathrm{Na}_{2} \mathrm{~S} \cdot 9 \mathrm{H}_{2} \mathrm{O}$ and $0.2 \mathrm{ml}$ of $10 \% \mathrm{NaHCO}_{3}$ (sterile, anaerobic solutions) and $0.05 \mathrm{ml}$ of filter-sterilized vitamin solution (Pfennig 1978) were injected into tubes before inoculation. For roll tubes media, 2\% agar (Difco) was added.

\section{Analytical techniques}

Volatile fatty acids, organic acids and alcohols were analysed as previously described (Cord-Ruwisch et al. 1986). Sulfide was measured spectrophotometrically as colloidal CuS (Cord-Ruwisch 1985). Bacterial growth was quantified by measuring the optical density at $580 \mathrm{~nm}$.

\section{Cell fractionation}

The cells ( $5 \mathrm{~g}$ wet weight) were suspended in $10 \mathrm{ml}$ of $50 \mathrm{mM}$ potassium phosphate buffer $(\mathrm{pH} 7.0)$ containing $1 \mathrm{mg}$ pancreatic deoxyribonuclease I and disrupted by passing them twice through a French pressure cell (Aminco) at $1,000 \mathrm{~atm}$. The broken cell suspension was centrifugated at $25,000 \times g$ for $20 \mathrm{~min}$ to remove cell debris. The resulting cell-free extract was separated into a supernatant and a particulate fraction by centrifugation at $140,000 \times g$ for $2 \mathrm{~h}$. The supernatant was considered as the soluble fraction. The dark gelatinous pellet was resuspended in the same buffer and represented the particulate fraction. Cell-free extracts ORSTOM Fonds Documentaire 


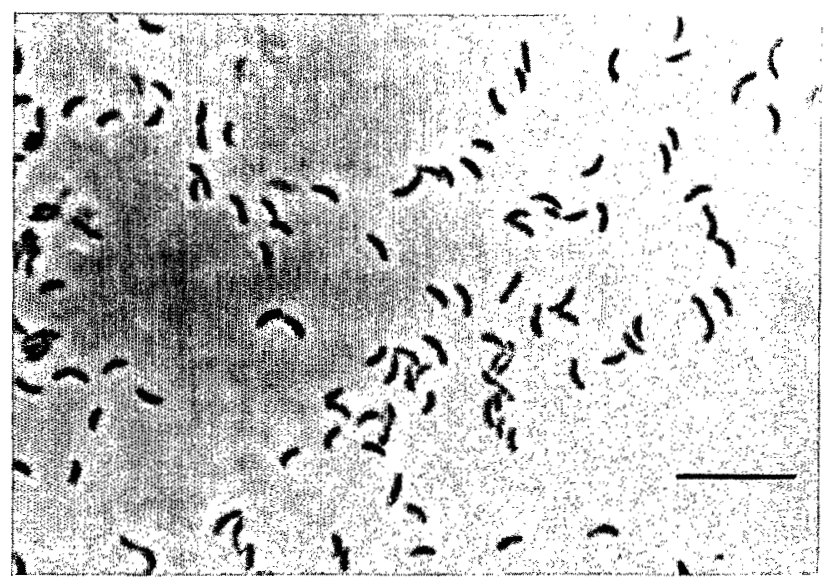

Fig. 1. Phase contrast photomicrograph of Desulfovibrio fructosovorans. Bar is $10 \mu \mathrm{m}$

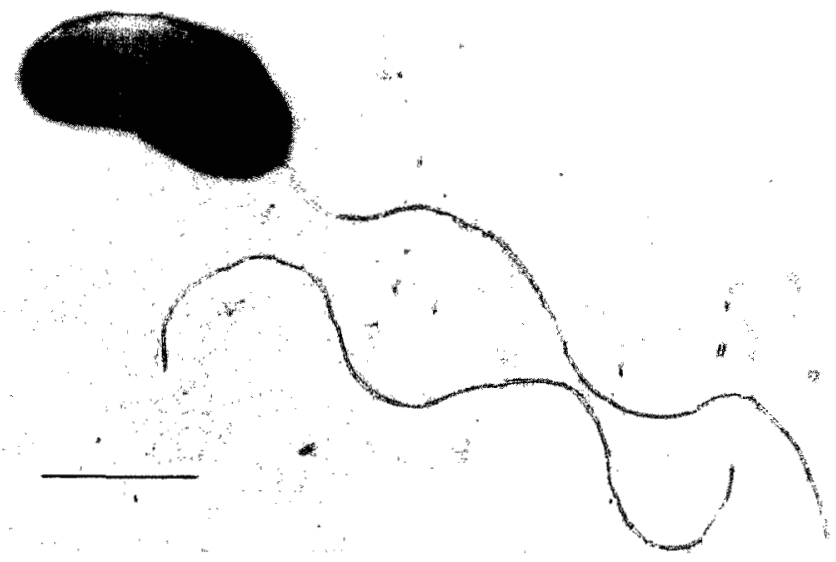

Fig. 2. Transmission electron micrograph of Desulfovibrio fructosovorans. Note the polar flagellum. Bar is $2 \mu \mathrm{m}$

were examined for cytochrome and desulfoviridin using a Cary 219 recording spectrophotometer. Protein was estimated by the method of Lowry et al. (1951) with bovine serum albumin as the standard.

\section{DNA extraction}

Whole-cell DNA was extracted after disruption of the cells and purified according to Marmur (1961) at the German Collection of Microorganisms (DSM), Göttingen, FRG; determination of $\mathrm{mol} \% \mathrm{G}+\mathrm{C}$ of the DNA was made by buoyant density centrifugation in a $\mathrm{CsCl}_{2}$ gradient.

\section{Results}

\section{Morphology}

Greyish round colonies appeared after 1 week of incubation in agar roll tubes at $37^{\circ} \mathrm{C}$. The isolate was a vibroid rod (Fig. 1) motile by a single polar flagellum (Fig. 2). It became spirilloid in old cultures. The cells were $0.5-0.7 \mu \mathrm{m}$ in diameter and $2-4 \mu \mathrm{m}$ in length. They occurred singly or in pairs. The cells stained Gram-negative. Spores were never observed.
Table 1. Utilization of various substrates as electron donors by Desulfovibrio fructosovorans in presence and in absence of sulfate

\begin{tabular}{lcc}
\hline Substrate $^{\mathrm{a}}$ & $+\mathrm{SO}_{4}^{2-}$ & $-\mathrm{SO}_{4}^{2-}$ \\
\hline $\mathrm{H}_{2}+\mathrm{CO}_{2}$ & + & - \\
Formate & + & - \\
Ethanol & $(+)$ & - \\
Glycerol & + & + \\
Lactate & + & - \\
Pyruvate & + & + \\
Malate & + & + \\
Fumarate & + & + \\
Fructose & + & + \\
\hline
\end{tabular}

$+:$ Substrates used as electron donors with increase of turbidity $(+)$ : Substrates used as electron donors without increase of turbidity a Substrates were tested at concentrations of $20 \mathrm{mM}$. Yeast extract and peptone were tested at concentration of $2 \mathrm{~g} / \mathrm{l}$. We also tested the following compounds which did not support sulfide production: acetate, propionate, butyrate, valerate, glutamate, succinate, oxamate, oxalate, choline, ribose, cellobiose, mannitol, inositol, xylose, mannose, inuline, melibiose, maltose, sucrose, galactose, arabinose, rhamnose, glucose, peptone, cysteine, lysine, tyrosine, phenylalanine, asparagine, glycine, tryptophan, arginine, ornithine, alanine. Growth was measured by determining $\mathrm{H}_{2} \mathrm{~S}$ or absorbancy after 7 days at $35^{\circ} \mathrm{C}$

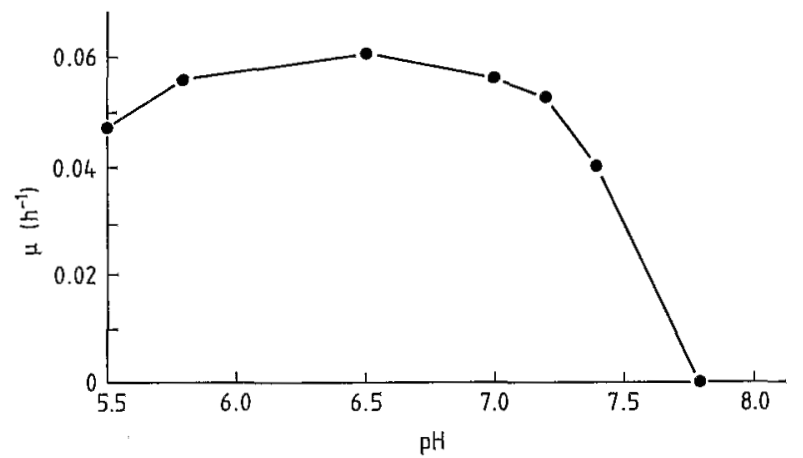

Fig. 3. Effect of $\mathrm{pH}$ on the growth rate of Desulfovibrio fructosovorans cultivated on fructose. Cultures were incubated at $35^{\circ} \mathrm{C}$

\section{Substrate and optimal conditions}

Nutritional studies were performed at $35^{\circ} \mathrm{C}$. Growth occurred in the absence of vitamins in the described medium as well as in medium for fatty acid-degrading sulfate-reducing bacteria (Widdel and Pfennig 1984). Elemental sulfur, sulfate, thiosulfate and sulfite served as electron acceptors. The isolate did not reduce nitrate. The compounds used as electron donors in sulfate containing medium are summarized in Table 1 . No growth was observed on other sugars or amino acids. Growth with molecular hydrogen or formate required acetate as carbon source. In the presence of sulfate, ethanol, glycerol, lactate and pyruvate were incompletely oxidized to acetate and $\mathrm{CO}_{2}$. Methanol was degraded after the cells had been grown on pyruvate but could not be used as the only energy source, even in the presence of acetate. Formate and methanol were oxidized to $\mathrm{CO}_{2}$.

Desulfovibrio strain JJ oxidized fructose, fumarate, pyruvate, malate and glycerol in the absence of sulfate. Fructose was fermented to succinate and acetate; small amounts of ethanol $(2 \mathrm{mM})$ was also produced. Fumarate and malate 


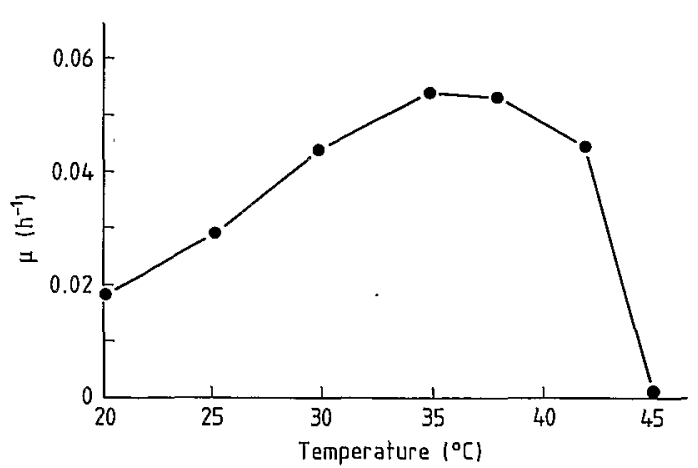

Fig. 4. Effect of temperature on the growth rate of Desulfovibrio fructosovorans cultivated on fructose. Cultures were incubated at $35^{\circ} \mathrm{C}$

were fermented to succinate and acetate. Pyruvate was fermented to mainly acetate. Fermentation products from glycerol were 3-hydroxypropionate and 1,3-propanediol. The isolate grew optimally in culture medium without additionally added $\mathrm{NaCl}$. No growth occurred when $40 \mathrm{~g}$ of $\mathrm{NaCl}$ per liter was added. The $\mathrm{pH}$ optimum for growth was between 6.5 and 7.0 (Fig. 3). The optimum growth temperature was $35^{\circ} \mathrm{C}$ (Fig. 4). In the presence of both sulfate and fumarate, fumarate was the preferred electron acceptor; sulfide was not produced.

\section{Pigments}

The soluble extract of Desulfovibrio strain JJ exhibited the characteristic absorption bands of cytochrome $c_{3}$ with maxima at $418.5,523$ and $552.5 \mathrm{~nm}$ when reduced with sodium dithionite. The oxidized extract showed an absorption maximum at $409 \mathrm{~nm}$. The cytochrome was not reduced by sodium ascorbate which indicated that it had a low midpoint redox potential. The spectrum showed in addition a strong absorption band at $628 \mathrm{~nm}$ and a weaker one centered at $580 \mathrm{~nm}$ characteristic of desulfoviridin (Postgate 1956; Lee and Peck 1971). Fluorescence test for desulfoviridin (Postgate 1959) of cell suspensions was positive.

\section{DNA base composition}

The mol\% G+C content of DNA of strain JJ was 64.13 (mean value of three determinations).

\section{Discussion}

Strain $\mathrm{JJ}$ is a curved rod able to reduce sulfate which does not form spores. The isolate oxidizes incompletely pyruvate and lactate to acetate $+\mathrm{CO}_{2}$. Neither acetate, propionate nor butyrate are oxidized by strain JJ. Based on these characteristics, the isolate can be affiliated to the genus Desulfovibrio (Pfennig et al. 1981). Like in other strains of this genus, the soluble extract of strain $\mathrm{JJ}$ exhibits the characteristic absorptions bands of cytochrome $c$ and desulfoviridin (Postgate 1956; Widdel and Pfennig 1984).

The isolate does not belong to the sapovorans group since it does not use saturated fatty acids. Morphological and physiological characteristics of strain JJ can be attributed to species Desulfovibrio desulfuricans and D. vulgaris (Widdel and Pfennig 1984) or to the newly described D. carbinolicus
(Nanninga and Gottschal 1986). It differs from $D$. desulfuricans by its ability to oxidize fructose and glycerol and its inability to use choline. In contrast with $D$. vulgaris, strain $\mathrm{JJ}$ is able to ferment fumarate and malate. The isolate differs from D. carbinolicus in the following ways: it does not use succinate; in the presence of sulfate, glycerol is converted to acetate and $\mathrm{H}_{2} \mathrm{~S}$; methanol cannot be used as the only energy source, even in the presence of acetate; the strain is motile. A characteristic which distinguishes strain $\mathrm{JJ}$ from the methanol oxidizing sulfate reducing bacterium isolated by Braun and Stolp (1985) is that it does not use peptones.

The most important difference between the isolate and all these described species is that strain JJ is the only Desulfovibrio strain known that uses a carbohydrate. In the presence of sulfate, fructose is converted to acetate and $\mathrm{H}_{2} \mathrm{~S}$ (Cord-Ruwisch et al. 1986). Beside sulfate, also thiosulfate, sulfite, elemental sulfur and fumarate serve as external electron acceptors. Organic substrates are also used in association with hydrogenophilic bacteria acting as electron acceptors (Cord-Ruwisch et al. 1986).

In the absence of sulfate, strain JJ metabolizes not only fructose but also fumarate and malate. Growth on fumarate (Miller and Wakerley 1966) and malate (Miller et al. 1970) was already reported for various Desulfovibrio strains. For each fumarate oxidized to acetate via malate and pyruvate, two fumarate molecules are reduced to succinate (Hatchikian and Le Gall 1970a,b; Hatchikian 1972). Succinate is also an end product of fructose fermentation. These results suggest that fumarate is probably an intermediary product and is used as electron acceptor during the fructose degradation. Strain JJ produces small amounts of ethanol during fructose fermentation. Similar results were obtained from fructose using homoacetogenic bacteria (Möller et al. 1984).

Sulfate-reducers are involved in the anaerobic microbial decomposition of organic matter and several results point out the fact that it might exist other nutritional types of sulfate-reducing bacteria in anaerobic environments (Jorgensen and Frenchel 1974; Pfennig et al. 1981). In 1980, Widdel described new morphological types of SRB. Braun and Stolp (1985) and Nanninga and Gottschal (1986) reported on the degradation of methanol by Desulfovibrio strains. Utilisation of fructose by strain JJ extends the range of substrates metabolized by this genus. The isolate is proposed as a new species in the genus Desulfovibrio: Desulfovibrio fructosovorans.

\section{Description of Desulfovibrio fructosovorans species nova}

Desulfovibrio fructosovorans sp. nov.; fruc.to.so.vo.rans. E.m.fructose; L.V.voro to devour; M.L.part.adj.fructosovorans devouring fructose.

Morphology. The cells are curved rods, motile by a single polar flagellum, $0.5-0.7 \mu \mathrm{m}$ wide and $2.0-4.0 \mu \mathrm{m}$ long, occurring singly or in pairs and becoming spirilloid in old cultures. Cells are Gram-negative and no spores were observed.

Physiology. Optimum growth occurs at $35^{\circ} \mathrm{C}$. The optimum $\mathrm{pH}$ for growth is between 6.5 and 7.0.

Nutrition. Strictly anaerobic. Elemental sulfur, sulfate, sulfite and thiosulfate serve as electron acceptors and are 
reduced to $\mathrm{H}_{2} \mathrm{~S}$. Nitrate is not reduced. Molecular hydrogen, formate, lactate, pyruvate, glycerol, fumarate, malate and fructose serve as electron donors. Growth with $\mathrm{H}_{2}$ and formate requires acetate as carbon source. Methanol is degraded after the cells have been grown on pyruvate. Fructose, pyruvate, malate, fumarate and glycerol are used in absence of sulfate. Not used: acetate, propionate, butyrate, succinate, oxamate, oxalate, choline. Vitamins are not required for growth. Sodium chloride is not required and is inhibitory above $4 \%(\mathrm{w} / \mathrm{v})$.

Pigments. Presence of desulfoviridin and cytochrome $c_{3}$.

DNA base ratio. $64.13 \mathrm{~mol} \% \mathrm{G}+\mathrm{C}$.

Type strain. Strain JJ is deposited in the German Collection of Microorganisms, Göttingen, FRG under the collection number DSM 3604.

Acknowledgements. We thank Dr. W. J. Jones for providing the strain JJ, Dr. J. C. Gottschal for providing D. carbinolicus for comparison study, Dr. H. Hippe for the determination of the DNA base ratio, G. Esnault for preparing the electron micrograph and I. Mathrani for perusing and reviewing the manuscript.

\section{References}

Balch WE, Fox GE, Magrum LJ, Wolfe RS (1979) Methanogens: reevaluation of a unique biological group. Microbiol Rev 43: $260-296$

Braun M, Stolp H (1985) Degradation of methanol by a sulfate reducing bacterium. Arch Microbiol 142:77-80

Cord-Ruwisch R (1985) A quick method for the determination of dissolved and precipitated sulfides in cultures of sulfate-reducing bacteria. J Microbiol Meth 4:33-36

Cord-Ruwisch R, Ollivier B, Garcia JL (1986) Fructose degradation by Desulfovibrio sp. in pure culture and in coculture with Methanospirillum hungatei. Curr Microbiol 13:285-289

Hatchikian EC (1972) Mécanismes d'oxydo-réduction chez les bactéries sulfato-réductrices. Thèse doctorat d'état, Université d'Aix-Marseille II, France

Hatchikian EC, Le Gall J (1970a) Étude du métabolisme des acides dicarboxyliques et du pyruvate chez les bactéries sulfato-réductrices. I. Étude de l'oxydation enzymatique du fumarate en acétate. Ann Inst Pasteur 118:125-142

Hatchikian EC, Le Gall J (1970 b) Étude du métabolisme des acides dicarboxyliques et du pyruvate chez les bactéries sulfato-réductrices. II. Transport des électrons, accepteurs finaux. Ann Inst Pasteur 118:288 - 301

Hungate RE (1969) A roll tube method for the cultivation of strict anaerobes. In: Norris JR, Ribbons DW (eds) Methods in microbiology, vol 3 B. Academic Press, New York, pp 117-132
Jones WJ, Guyot JP, Wolfe RS (1984) Methanogenesis from sucrose by defined immobilized consortia. Appl Environ Microbiol $47: 1-6$

Jorgensen BB, Frenchel $T$ (1974) The sulfur cycle of a marine sediment model system. Marine Biol 24:189-201

Klemps R, Cypionka H, Widdel F, Pfennig N (1985) Growth with hydrogen, and further physiological characteristics of Desulfotomaculum species. Arch Microbiol 143:203-208

Lee JP, Peck HD Jr (1971) Purification of the enzyme reducing bisulfite to trithionate from Desulfovibrio gigas and its identification as desulfoviridin. Biochem Biophys Res Commun 45:583- 589

Lowry OH, Rosebrough NJ, Farr AL, Randall RJ (1951) Protein measurement with the Folin phenol reagent. J Biol Chem $193: 265-275$

Marmur J (1961) A procedure for the isolation of deoxyribonucleic acid from microorganisms. J Mol Biol 3:2317-2324

Miller JDA, Wakerley DS (1966) Growth of sulphate-reducing bacteria by fumarate dismutation. J Gen Microbiol 43:101-107

Miller JDA, Neuman PM, Elford L, Wakerley DS (1970) Malate dismutation by Desulfovibrio. Arch Microbiol 71:214-219

Möller B, Obmer R, Howard BH, Gottschalk G, Hippe H (1984) Sporomusa, a new genus of Gram-negative anaerobic bacteria including Sporomusa sphaeroides spec. nov. and Sporomusa ovata spec. nov. Arch Microbiol 139:388 -396

Nanninga HJ, Gottschal JC (1986) Isolation of a sulfate-reducing bacterium growing with methanol. FEMS Microbiol Ecol $38: 125-130$

Pfennig N (1978) Rhodocyclus purpureus gen. nov. and sp. nov., a ring shape, vitamin $B_{12}$-requiring member of the family Rhodospirillaceae. Int J Syst Bacteriol 28:283-288

Pfennig N, Widdel F, Trüper HG (1981) The dissimilatory sulfatereducing bacteria. In: Starr $M P$, Stolp $H$, Trüper $H G$, Balows A, Schlegel HG (eds) The prokaryotes. Springer, Berlin Heidelberg New York, pp 926-940

Postgate JR (1956) Cytochrome $c_{3}$ and desulphoviridin; pigments of the anaerobe Desulphovibrio desulphuricans. J Gen Microbiol $14: 545-572$

Postgate JR (1959) A diagnostic reaction of Desulphovibrio desulphuricans. Nature 183:481-482

Postgate JR (1979) The sulfate reducing bacteria. Cambridge University Press, London

Stams AJM, Hansen TA, Skyring GW (1985) Utilization of amino acids as energy substrates by two marine Desulfovibrio strains. FEMS Microbiol Ecol 31:11-15

Widdel F (1980) Anaerober Abbau von Fettsäuren und Benzoesäure durch neu isolierte Arten Sulfat-reduzierender Bakterien. Doctoral thesis, Univ Göttingen, FRG

Widdel F, Pfennig N (1984) Dissimilatory sulfate- or sulfur-reducing bacteria. In: Krieg NR, Holt JG (eds) Bergey's manual of systematic bacteriòlogy, 9th edn. Williams and Wilkins, Baltimore, pp 663-679

Received July 31, 1987/Accepted November 19, 1987 